\title{
HUBUNGAN TINDAKAN CUCI TANGAN PAKAI SABUN DENGAN KEJADIAN DIARE PADA BALITA DI RW XI KELURAHAN SIDOTOPO, KECAMATAN SEMAMPIR, KOTA SURABAYA
}

\author{
Aulia Radhika \\ Promosi Kesehatan dan Ilmu Perilaku, Universitas Airlangga \\ Email: radhikaaulia@gmail.com
}

\begin{abstract}
Diarrhea is one of health systems that are often found in the community with characterized by defecation more than three times a day. Based on data from Sidotopo community health center showed that diarrhea included in the 6 highest disease in Poli Umum with the most time at 1 until 4 years old found as many as 685 cases. Hand is a major disease germ therefore it is one way to deal with various infectious diseases such as diarrhea. The purpose of this study to determine the relationship between children under five in RW XI Sidotopo, Semampir sub-district of Surabaya using observation using cross sectional approach. The sample was determined by Cluster Random Sampling method. Toddlers in RW XI Sidotopo diarrhea behind 33 children from 60 respondents. from result of analysis of calculation of relation by using chi square obtained result $p=0,013$ with $\alpha=0,05(p<\alpha)$ Can give information about relation between handwashing behavior of soap with incident of diarrhea in toddler in RW XI of Sidotopo sub-district of Semampir City Surabaya The incidence of diarrhea in Surabaya sidotopo are caused by several factors, namely the wrong society and environment because it is because no treatment is done by parents and children.
\end{abstract}

Keywords: Toddler, Hand Washing with Soap, Diarrhea, Environment

\begin{abstract}
ABSTRAK
Diare merupakan satu dari banyak penyakit yang sering di temui di masyarakat. Diare berhubungan dengan system pencernaaan yang ditandai dengan buang air besar encer lebih dari tiga kali dalam sehari. Berdasarkan data puskesmas Sidotopo menunjukkan bahwa diare masuk dalam enam penyakit teringgi di poli umum dengan rentang usia terbanyak pada usia satu sampai dengan empat tahun. ditemukan sebanyak 685 kasus. Tangan merupakan perantara penyebaran kuman penyakit, oleh karena itu perilaku cuci tangan pakai sabun merupakan salah satu cara untuk mencegah timbulnya mata rantai penyebaran berbagai penyakit menular seperti diare. Tujuan penelitian ini adalah menganalis hubungan antara tindakan cuci tangan pakai sabun dengan kejadian diare pada balita di RW XI kelurahan Sidotopo, kecamatan Semampir Kota Surabaya. Jenis penelitian ini observasional dengan menggunakan pendekatan cross sectional, Sampel ditentukan dengan metode Cluster Random Sampling. Balita di RW XI Kelurahan Sidotopo yang mengalami diare berjumlah 33 balita dari 60 responden. dari hasil perhitungan hubungan dengan menggunakan chi square didapatkan hasil $\mathrm{p}=0,013$ dengan $\alpha=0,05(\mathrm{p}<\alpha)$ sehingga dari hasil tersebut dapat diartikan terdapat hubungan antara perilaku cuci tangan pakai sabun dengan kejadian diare pada balita di RW XI kelurahan Sidotopo Surabaya. Kejadian diare di kelurahan sidotopo Surabaya disebabkan oleh beberapa faktor yaitu tindakan masyarakat dan lingkungan salah satunya adalah karena cuci tangan
\end{abstract}


yang tidak benar dengan demikian diperlukan perhatian khusus sejak dini oleh orangtua kepada balita dengan cara praktis untuk memutus salah satu rantai penyebaran diare dengan cuci tangan pakai sabun.

Kata kunci: Balita, Cuci Tangan Pakai Sabun, Diare, Lingkungan

\section{PENDAHULUAN}

Balita merupakan golongan umur yang mudah terserang berbagai berbagai macam penyakit. Daya tahan yang masih rendah memungkinkan timbulnya keadaan yang demikian. Masa balita merupakan masa di mana orangtua ikut berperan sangat penting dalam mengasuh buah hatinya terutama ibu, sehingga masalah kesehatan pada balita tidak bisa dianggap remeh karena berhubungan dengan orangtua. Diare merupakan masalah yang sering ditemui di masyarakat. Buang air besar encer lebih dari tiga kali dalam sehari dapat dikatakan bahwa seseorang terkena diare. ${ }^{1}$

Diare mempunyai banyak penyebab, salah satu penyebab dari timbulnya diare adalah kehilangan cairan dan elektrolit melalui feses apabila parah bias sampai pada timbulnya kematian. Penyebab lainnya adalah bisa karena penyakit lain seperti disentri, kurang gizi, dan infeksi. Balita yang mengalami diare dengan intensitas yang tinggi akan timbul kekurangan cairan dalam tubuh. Kekurangan cairan tubuh atau dehidrasi dikategorikan menjadi diare tanpa dehidrasi, dehidrasi ringan, sedang ataupun berat. ${ }^{2}$ Diare perlu mendapat perhatian khusus karena merupakan salah satu masalah kesehatan dengan angka mortilitas cenderung tinggi. Penyakit diare masih dianggap menjadi penyebab utama kematian bayi dan balita di Indonesia menurut data Riskesdas tahun $2007 .^{3}$ Angka prevalesi diare di Indonesia masih berfluktuasi. Prevalensi diare klinis yaitu sebesar $9.0 \%$ rentang (4.2\%-18.9\%) kasus tertinggi di Provinsi NAD sebeesar $18.9 \%$ dan terendah di Yogyakarta sebesar 4.2\%. Diare klinis dengan prevalensi tinggi lebih dari $9.0 \%$ yaitu di Provinsi Sumatera Barat, NAD, Riau, Jawa Barat, Jawa Tengah, Banten, NTT, NTB, Kalimantan Selatan, Sulawesi Tenggara, Gorontalo, Papua Barat serta Papua menurut Riskesdas 2007. Data dari Riskesdas tahun 2013 angka prevalensi menurun (3.5\%) untuk semua kelompok umur. Kejadian tertinggi pada anak usia kurang dari satu tahun sebesar 5.5\% sedangkan pada umur satu tahun 5,1\%. ${ }^{4}$

Data diare dari profil kesehatan Jawa Timur tahun 2015 menurut Kota Kabupaten menunjukan bahwa kejadian diare di Surabaya tertinggi di Jawa Timur dibandingkan kota atau kabupaten yang lain mencapai 2.848 .583 orang. ${ }^{5}$ Berdasarkan data Puskesmas Sidotopo menunjukkan bahwa diare masuk dalam enam penyakit teringgi di poli umum dengan rentang usia terbanyak pada usia satu sampai dengan empat tahun. ditemukan sebanyak 685 kasus. ${ }^{6}$

Data yang demikian menunjukan bahwa kejadian diare sangat perlu diperhatikan di Kota 
Surabaya. Tangan merupakan perantara pembawa kuman penyakit, dalam hal ini untuk memutus mata rantai diare salah satu cara yang dapat dilakukan dan merupakan hal yang sangat penting adalah tindakan cuci tangan pakai sabun. Praktek CPTS merupakan tindakan yang sangat mudah dan praktis di terapkan karena berhubungan dengan keseharian yang dilakukan namun banyak orang masih mengabaikan pentingnya CPTS. Tindakan ini dapat mencegah timbulnya infeksi kulit, mata, dan prang orang dengan HIV/AIDS ataupun ODHA. ${ }^{7}$

Penelitian serupa menunjukan hasi bahwa terdapat hubungan Perilaku Cuci Tangan Pakai Sabun dengan terjadinya Diare pada Anak Sekolah Dasar di SD Advent Sario. ${ }^{8}$ Tindakan cuci tangan menggunakan sabun merupakan intervensi yang dapat dijangkau oleh semua golongan Penelitian. ${ }^{9}$

Penelitian ini dilakukan di RW XI Kelurahan Sidotopo, Kecamatan Semampir Kota Surabaya yang didasarkan dari data sekunder P2 Puskesmas Sidotopo tahun 2017. Informasi yang diperoleh diketahui bahwa kejadian diare ditemukan sebanyak 685 kasus pada usia rentang 1-4 tahun. Studi pendahuluan yang dilakukan terhadap 110 warga RW XI Kelurahan Sidotopo. Kemudian dilakukan penyebaran kuesioner mendalam kepada $60 \mathrm{ibu}$ dengan balita dan diketahui bahwa tindakan mencuci tangan dengan menggunakan sabun masih rendah dan perlu dicari hubunganya dengan terjadinya diare.
Tujuan dari penelitian ini adalah untuk hubungan Antara tindakan cuci tangan menggunakan sabun dengan kejadian diare pada balita di RW XI kelurahan Sidotopo, Kecamatan Semampir, Surabaya.

\section{METODE PENELITIAN}

Penelitian yang dilakukan merupakan jenis penelitian observasional dengan menggunakan pendekatan cross sectional untuk melihat hubungan antara variabel bebas dan terikat dalam waktu bersamaan, yaitu hubungan tindakan cuci tangan menggunakan sabun dengan kejadian diare pada balita.

Sampel ditentukan dengan metode Cluster Random Sampling yang kemudian dilakukan penghitungan dengan rumus solvin didapatkan hasil sampel sebanyak 60 balita dari 150 balita di RW XI kelurahan Sidotopo. Sampel yang diambil dalam penelitian ini adalah balita umur 6-48 bulan. Sampel tersebut merupakan sebagian dari keseluruhan objek sehingga dianggap mewakili populasi sampel balita yang ada di RW XI Sidotopo. Pengambilan data dilakukan dengan penyebaran kuesioner tentang tindakan cuci tangan pakai sabun dengan kejadian diare selama 3 bulan terakhir.

Analisis data dilakukan dengan menganalisis secara deskriptif dan analitik. Analisis deskriptif digunakan untuk mendeskripsikan variabel yang diteliti meliputi tindakan cuci tangan pakai sabun dan kejadian diare, kemudian ditampilkan dalam bentuk tabel 
distribusi frekeunsi. Analisis analitik digunakan analisis bivariat yaitu untuk menguji hubungan kebiasaan cuci tangan pakai sabun dengan kejadian diare digunakan uji Chi Square.

\section{HASIL DAN PEMBAHASAN}

Orangtua sebagai contoh yang ditiru dan menjadi panutan untuk anak sehingga melalui orangtua (keluarga terdekat) tindakan tersebut muncul. Cuci tangan dengan benar juga dipengaruhi oleh air yang digunakan untuk mencuci tangan. Tangan adalah bagian dari tubuh yang mudah terkena kotoran dan tertempel kuman penyakit. Ketika menggenggam sesuatu, menyentuh, membersih-kan organ vital setelah atau sebelum buang air besar atau buang air kecil dan bersalaman, kegiatan demikian dapat menimbulkan bibit penyakit melekat pada kulit tangan dan masuk secara oral lewat mulut karena kurang bersihnya dalam mencuci tangan dengan kuman penyakit yang masih menempel pada tangan.

Dilihat dari kerentanan terjadinya transmisi penyakit melalui tangan yang dapat masuk kedalam tubuh secara oral salah satu cara yang dapat dilakukan adalah dengan cara cuci tangan dengan menggunakan sabun sebelum atau sesudah beraktivitas hal tersebut dilakukan salah satunya untuk memutus mata rantai diare. Diare disertai muntah dan buang air besar encer sering terjadi kepada anak, bila tidak ditangani, diare dapat berakibat kekurangan cairan tubuh (dehidrasi). ${ }^{10}$ Data P2 Puskesmas Sidotopo
2017, diketahui bahwa kejadian diare ditemukan sebanyak 685 kasus pada usia rentang 1-4 tahun. 6

Pengambilan sampel kuesioner dilakukan pada ibu yang mempunyai bayi atau balita yang ada di Kelurahan sidotopo RW XI sebanyak 60 orang dengan rentang usia dari 6 bulan- 48 bulan. Karakteristik responden adalah sebagai berikut: Tabel 1 Karateristik Responden

\begin{tabular}{lrr}
\hline Karateristik & $\begin{array}{c}\text { Frekuensi } \\
(\mathrm{n})\end{array}$ & $\begin{array}{c}\text { Persentase } \\
(\%)\end{array}$ \\
\hline Usia balita & & \\
\hline $6-24.9$ bulan & 28 & 47,00 \\
$25-36.9$ bulan & 14 & 23,00 \\
$>37$ bulan & 18 & 30,00 \\
\hline Pendidikan orangtua & & \\
\hline Tidak sekolah & 2 & 3,00 \\
SD & 23 & 39,00 \\
SMP & 21 & 35,00 \\
SMA & 14 & 23,00 \\
\hline
\end{tabular}

Dari data tersebut menunjukan bahwa rentang usia bayi dan balita menunjukan rentang 6 bulan sampai dengan 24.9 bulan sebanyak 28 bayi dan balita, rentang umur 25 bulan - 36.9 bulan sebanyak 16 balita dan rentang usia lebih dari 37 bulan sebanyak 18 balita.

Penghasilan orangtua dari bayi dan balita yang ada di RW 11 Kelurahan Sidotopo terbanyak berkisar kurang dari Rp.1000.000 yang tergolong rendah sampai dengan $\mathrm{Rp}$. 3.500.000 tergolong cukup.Penghasilan dapat memengaruhi social ekonomi masyarakat sekitar hingga timbulnya penyakit diare di wilayah RW XI. Karena dengan pendapatan 
rendah dapat mengurangi kemampuan orangtua untuk peduli terhadap kesehatan balitanya dan dirinya. Dengan keadaan demikian dimungkinkan cenderung memiliki higiene yang kurang terhadap lingkungan rumah dan kebersihan diri dan juga konsumsi makanan sembarangan sehingga dapat timbul penyakit diare.

Latar belakang pendidikan responden paling banyak adalah SD yaitu sebanyak 39\% dengan jumlah responden 23 orang. Hal tersebut menunjukan bahwa latar belakang pendidikan dari orangtua bayi dan balita tersebut tergolong rendah. Cara berfikir seseorang dapat dipengaruhi oleh tingkat pendidikan yang pernah didapatkan atau diperoleh sehingga akan berpengaruh ke tindakan yang akan mereka lakukan. Pendidikan yang dimiliki orangtua merupakan salah satu tolak ukur keadaan sosial sehingga dapat dilihat pola pikir orangtua tentang masalah-masalah kesehatan terutama pengetahuan tentang penyakit diare sehingga dapat melakukan tindakan seperti pengetahuan tentang bahaya diare, ciri-ciri dari diare, cara transmisi penyakitnya dan cara mencuci tangan dengan baik dan benar. Penyakit dapat dihindari dengan adanya kemauan dan pencarian informasi tentang kepedulian terhadap kesehatan terutama pengetahuan tentang diare, ciri-ciri dan dampak yang ditimbulkan, dan cara yang dapat dilakukan untuk mengurangi timbulnya diare dengan kepedulian terhadap sanitasi lingkungan sehingga penyakit diare dapat diminimalisir.
Hasil dari kuesioner yang dibagikan ke masyarakat sebanyak 60 kuesioner yang mempunyai bayi dan balita didapatkan sebanyak 33 responden mengalami diare dalam 3 bulan terakhir. Berikut merupakan table kejadian diare di wilayah RW 11, Kelurahan Sidotopo, Kecamatan Semampir.

Tabel 2 Kejadian Diare

\begin{tabular}{lrr}
\hline Kejadian Diare & $\begin{array}{c}\text { Frekuensi } \\
(\mathrm{n})\end{array}$ & $\begin{array}{c}\text { Persentase } \\
(\%)\end{array}$ \\
\hline Ya & 33 & 55,00 \\
\hline Tidak & 27 & 45,00 \\
\hline
\end{tabular}

Diare merupakan penyakit yang serius pada balita jika tidak di cegah dan ditangani dengan cepat Kejadian diare di kelurahan Sidotopo Surabaya disebabkan oleh beberapa faktor yaitu tindakan masyarakat dan lingkungan tindakan tersebut disebabkan karena cuci tangan yang tidak benar, pengetahuan kurang, buang sampah sembarangan, buang air besar di sungai kemudian tidak mencuci tangan setelah buang air besar atau setelah beraktifitas sehingga tertular ke makanan dan jajan sembarangan. Pada faktor lingkungan dapat disebabkan karena ditemukan adanya tempat sampah yang terbuka, sebagian besar warga tidak memiliki septic tank, makanan dijual secara terbuka, pengolahan makanan dekat dengan tempat dimana mereka buang air besar atau buang air kecil dikarenakan banyak rumah yang langsung terhubung dengan kali dengan alas kayu diatas kali sebagai pijakan saat buang 
air sehingga mereka langsung membuang tinja mereka di kali, terdapat lalat yang hinggap dan dapat menyebarkan penyakit lewat lalat tersebut. kurangnya lahan juga memengaruhi dikarenakan tanah yang digunakan untuk tinggal merupakan tanah milik PJKA sehingga tidak boleh menggali tanah untuk saptic tank ataupun kamar mandi sehingga akibat terbatasnya lahan kebanyakan buang air di sungai ataupun kali.

Tindakan merupakan realisasi dari pengetahuan dan sikap dengan suatu perbuatan nyata. ${ }^{11}$ Didalam konteks ini tindakan responden merupakan perbuatan nyata dari orangtua balita yang berkaitan dengan cuci tangan pakai sabun. Berikut tabel yang menunjukan tindakan cuci tangan:

Tabel 3 Tindakan Cuci Tangan Menggunakan Sabun

\begin{tabular}{lrr}
\hline Tindakan & $\begin{array}{c}\text { Frekuensi } \\
(\mathrm{n})\end{array}$ & \multicolumn{1}{c}{$\begin{array}{c}\text { Persentase } \\
(\%)\end{array}$} \\
\hline Kadang & 42 & 70,00 \\
\hline Sering & 13 & 21,60 \\
\hline Selalu & 5 & 8,40 \\
\hline
\end{tabular}

Tabel di atas menunjukan bahwa responden kadang mencuci tangan mereka menggunakan sabun sebelum atau setelah beraktifitas sehingga memungkinkan kontaminasi apabila kontak dengan balita. Mereka beranggapan bahwa mencuci tangan dengan menggunakan air tanpa sabun sudah cukup. Padahal melalui tangan yang kotor penyakit dapat masuk ke dalam saluran pencernaan secara oral bisa karena menyentuh makanan saat tangan kotor sehingga kontaminasi bakteri menempel pada makanan dan termakan, selanjutnya dengan tidak mencuci tangan saat buang air besar atau kecil kemudian langsung memegang makanan dan masuk melalui mulut sehingga hal tersebut berpotensi menimbulkan diare. ${ }^{12}$ Mencegah terjadinya diare dapat dimulai dari sendiri dengan memberikan makanan ng hygenis dan tidak lupa juga untuk selalu mencuci tangan dengan sabun sampai bersih.

\section{Hubungan Tindakan Cuci Tangan Pakai Sabun dengan Kejadian Diare}

Berdasarkan hasil penelitian pada 60 responden ibu yang mempunyai balita di RW XI Kelurahan Sidotopo tentang hubungan Antara tindakan cuci tangan pakai sabun dengan Kejadian Diare, dari hasil perhitungan hubungan dengan menggunakan chi square didapatkan hasil $\mathrm{p}=0,013$ dengan $\alpha=0,05(\mathrm{p}<\alpha)$ sehingga dapat diartikan bahwa terdapat hubungan antara tindakan cuci tangan menggunakan sabun dengan kejadian diare pada balita di RW XI kelurahan Sidotopo Kota Surabaya.

Pada Tabel 4 menunjukan hasil bahwa balita yang terkadang mencuci tangan dengan sabun akan lebih banyak terkena diare sebesar $66,7 \%$ dari 42 balita. Sedangkan balita yang sering mencuci tangan, hasil dari data menunjukkan bahwa $8.1 \%$ balita terkena diare. Sehingga menunjukan hasil bahwa orang yang sering dan selalu mencuci tangan dengan menggunakan sabun lebih kecil risiko terkena diare. 
Tabel 4 Hubungan Tindakan CPTS dengan Kejadian Diare

\begin{tabular}{lrrr}
\hline \multirow{2}{*}{$\begin{array}{c}\text { Tindakan cuci } \\
\text { tangan }\end{array}$} & \multicolumn{2}{c}{ Kejadian Diare } & total \\
\cline { 2 - 3 } & \multicolumn{1}{c}{ Ya } & Tidak & \\
\hline Kadang & 28 & 14 & 42 \\
Sering + selalu & 5 & 13 & 18 \\
\hline \multicolumn{2}{c}{ Chi -square $\mathrm{p}=0,013(\alpha=0,05)$} \\
\hline
\end{tabular}

Penelitian ini selaras dengan hasil dari penelitian ilham tahun 2014 yang menunjukan adanya hubungan antara Perilaku cuci tangan dengan menggunakan sabun dengan kejadian Diare pada Anak Sekolah Dasar di SD Advent Sario. ${ }^{8}$ Tindakan cuci tangan menggunakan sabun merupakan intervensi yang dapat dijangkau oleh semua golongan Penelitian. ${ }^{9}$

Hasil yang diteliti ini sesuai Kejadian yang timbul di RW 11 kelurahan Sidotopo sebagian besar yang mengalami diare disebabkan oleh kebiasaan yang mereka lakukan sendiri setiap harinya. Seperti pengolahan makanan dekat dengan tempat dimana mereka buang air besar atau buang air kecil karena tidak mempunyai saptic tank sendiri sehingga bakteri dapat tebawa melalui perantara udara, tangan, binatang atau yang lainya. Hal tersebut dimungkinkan juga karena letak dari sebagian rumah ibu dari balita berada di pinggir rel kereta api yang berdekatan dengan sungai kemudian banyaknya penjual makanan rumahan yang ada di pinggir jalan atau kali sehingga potensi timbulnya kontaminasi menjadi lebih besar. Pembersihan botol susu bayi perlu diperhatikan juga karena sebagian besar ibu hanya membersihkan botol susu dengan sabun dan dibilas tanpa dipanaskan lebih lanjut untuk membunuh kuman yang terdapat di botol tersebut yang dapat meningkatkan resiko terjaidnya diare, buang sampah sembarangan, buang air besar di sungai tidak mencuci tangan setelah buang air besar atau setelah beraktifitas sehingga tertular ke makanan kemudian saat menyuapi balita lewat alat makan seperti sendok atau piring yang belum dicuci bersih kemudian kontaminasi masuk kedalam tubuh apabila daya tahan tubuh balita lemah tidak tahan, menimbulkan gangguan pencernaan dan dapat mengakibatkan diare,

Meningkatkan derajat kesehatan masyarakat merupakan salah satu penerapan perilaku hidup bersih yang dapat dilakukan dengan kebiasaan mencuci tangan dengan sabun, hal tersebut merupakan salah satu dari tiga pilar pembangunan bidang kesehatan yakni perilaku hidup sehat, penciptaan lingkungan yang sehat serta penyediaan layanan kesehatan yang bermutu dan terjangkau oleh semua lapisan masyarakat.

Perhatian khusus sejak dini kepada balita dengan cara praktis untuk memutus salah satu rantai penyebaran diare dengan Cuci tangan pakai sabun. Cara yang benar adalah diperlukan adanya sabun dan air mengalir. Air mengalir tidak harus dari kran, air tersebut dapat juga dari sebuah wadah seperti ember, gayung botol, kaleng, gentong, jerigen, Tangan yang basah disabuni, digosok-gosok kemudian menelungkupkan tangan secara bergantian bagian telapak 
maupun punggungnya, kemudian gerakan mengatup dan mengunci untuk membersihkan sela jari dan kuku minimal 20 detik, kemudian dilakukan pembersihan ibu jari dan gosok ujung jari, kemudian dibilas dengan air mengalir dan mengeringkannya menggunakan kain, tisu bersih atau kibas-kibaskan di udara.

\section{SIMPULAN DAN SARAN}

\section{Simpulan}

Balita di RW XI Kelurahan Sidotopo yang mengalami diare berjumlah 33 balita dari 60 responden. Hasil penghitungan menunjukkan terdapat hubungan antara tindakan cuci tangan pakai sabun dengan kejadian diare pada balita di RW XI Kelurahan Sidotopo Kota Surabaya. Hal disebabkan oleh beberapa faktor yaitu cara cuci tangan yang kurang benar, banyak ibu dari balita jarang mencuci tangan dengan meenggunakan sabun, buang air besar di sungai, tidak mencuci tangan setelah buang ar besar, suka jajan sembarangan,

\section{Saran}

Meningkatkan perilaku hidup bersih danj sehat (PHBS), dimulai dari cara mencuci tangan yang benar setelah ataupun sebelum beraktivitas dengan meenggunakan sabun dan air mengalir, tidak melakukan buang air besar di sungai, dan jajan sembarangan,

\section{REFERENSI}

1. World Health Organization. Diarrhoea Treatment Guidelines Including New Recommendations For The Use of ORS and
Zinc Supplementation for Clinic- Based and Healthcare Workers. USA: MOST The USAID Micronutrient Programt Kerja Puskesmas. Kesehatan Lingkungan, pp. 113. 2009.

2. Widoyono. Penyakit Tropis: Epidemiologi, Penularan, Pencegahan \& Pemberantasannya. Edisi Kedua. Erlangga. Ciracas: 193199. 2011.

3. Badan Penelitian dan Pengembangan Kesehatan. Riset Kesehatan Dasar (RISKESDAS 2013). Jakarta: Kementerian Kesehatan RI. 2007.

4. Badan Penelitian dan Pengembangan Kesehatan. Riset Kesehatan Dasar (RISKESDAS 2013). Jakarta: Kementerian Kesehatan RI. 2013.

5. Dinas Kesehatan Provinsi Jatim. Profil Kesehatan Provinsi Jawa Timur Tahun 2012. Surabaya: Dinas Kesehatan Provinsi Jawa Timur. 2015.

6. Dinas Kesehatan Kota Surabaya. Profil Kesehatan Kota Surabaya Tahun 2017. Surabaya: Dinas Kesehatan Kota Surabaya. 2018.

7. Subea D. Raih Hidup Sehat Dengan Cuci Tangan Pakai Sabun - Hari Cuci Tangan Pakai Sabun Sedunia (HCTPS). 2010. http://www.depkes.go.id.

8. Ilham, B.S. Hubungan Perilaku Cuci Tangan Pakai Sabun Dengan Kejadian Diare Di Sd. jurnal kedokteran komunitas dan tropik, 2014.

9. Fewtrell L \& Kaufman R. Water, sanitation, and hygiene interventions to reduce diarrhoea in less developed countries: a systematic review and meta-analysis. Lancet Infect Dis, 5(1):42-52. 2005.

10. Departemen Kesehatan RI. Buku Saku Diare Edisi 2011. Jakarta: Departemen Kesehatan RI. 2011.

11. Notoatmodjo, Soekidjo. Metodologi Penelitian Kesehatan Rineka Cipta: Jakarta. 2015. 
12. Fathonah, S. Hygiene dan Sanitasi makanan. Semarang: Universitas negeri Semarang Press. 2005.

13. Rosidi, A.E.H. Hubungan Kebiasaan Cuci Tangan Dan Sanitasi Makanan Dengan Kejadian Diare Pada Anak Sd Negeri Podo 2 Kecamatan Kedungwuni Kabupaten Pekalongan. Jurnal Kesehatan Masyarakat Indonesia, 6(1) 76-84. 2010.

14. Ristiawan, M. Hubungan Kualitas Bakteriologis Air Hippam Dengan Kejadian Diare Pada Balita Di Wilayah Kerja Puskesmas. Kesehatan Lingkungan, 1-13. 2015. 